\title{
Effects of Aerobic Conditioning on Individuals Post-Stroke: What Is the Evidence?
}

\author{
Roberta Lins Gonçalves ${ }^{1,2 *}$, Ingrid de Fátima Aquino Suzuki ${ }^{3}$, Fernanda Figueiroa Sanchez ${ }^{3}$, \\ Elisa Brosina De Leon ${ }^{3}$, Peterson Marco de Oliveira Andrade ${ }^{4}$ \\ ${ }^{1}$ Physiology and Pharmacology, Federal University of Amazonas, UFAM, Amazonas, Brazil \\ ${ }^{2}$ Campus Universitário Senador Arthur Virgílio Filho, Faculdade de Educação Física e Fisioterapia-FEFF, \\ UFAM, Amazonas, Brazil \\ ${ }^{3}$ UFAM, Amazonas, Brazil \\ ${ }^{4}$ UFJF, Minas Gerais, Brazil \\ Email: "betalinsfisio@yahoo.com.br,.Ingrid_dhc@hotmail.com,fersanchez1@hotmail.com, \\ elisadleon@yahoo.com.br, petersonmarco@yahoo.com.br
}

Received 27 January 2016; accepted 25 March 2016; published 28 March 2016

Copyright @ 2016 by authors and Scientific Research Publishing Inc.

This work is licensed under the Creative Commons Attribution International License (CC BY). http://creativecommons.org/licenses/by/4.0/

(c)

\section{Abstract}

Background: Stroke has been considered the major cause of chronic disability in the world and ranks among the leading causes of death. Despite the fact that new vascular events often happen and risk factors are the same that Cardiovascular Diseases, secondary prevention through nonpharmacological measures, are not part of the routine physical rehabilitation after stroke. Objective: The aim is to answer the following clinical question: Should aerobic fitness be part of the physical rehabilitation of individuals post-stroke? Methodological Design: The methodology used in the study was an integrative literature review. Inclusion Criteria: Articles in English are published in secondary databases: systematic reviews with or without meta-analysis, which address the question PICO: patient (post-stroke), intervention (aerobic exercise), comparison (with or without aerobic conditioning) the outcome (volume of oxygen consumed peak $\left(\mathrm{VO}_{2 \text { peak }}\right)$, quality of life (QoL), morbidity and mortality). Outcomes: $\mathrm{VO}_{2 \text { peak, }} \mathrm{QoL}$, complications and mortality. Analysis of Studies: The methodological quality of included studies is assessed using the tools: PRISMA and R-AMSTAR. Results: There was "good" evidence for the inclusion of aerobic exercise on physical rehabilitation of post-stroke individuals to improve their physical capacity $\left(\mathrm{VO}_{2 \text { peak }}\right)$, facilitating the completion of activities of daily living and gait. There was weak evidence on the association of aerobic fitness with positive results on QoL in stroke victims and insufficient results to evaluate the effect of aerobic fitness on the risk of stroke recurrence and mortality. Conclusion: The aerobic

\footnotetext{
*Corresponding author.
}

How to cite this paper: Gonçalves, R.L., de Fátima Aquino Suzuki, I., Sanchez, F.F., De Leon, E.B. and de Oliveira Andrade, P.M. (2016) Effects of Aerobic Conditioning on Individuals Post-Stroke: What Is the Evidence? International Journal of Clinical Medicine, 7, 245-260. http://dx.doi.org/10.4236/ijcm.2016.73026 
conditioning should be included in the rehabilitation of stroke victims.

Keywords

Post-Stroke, Aerobic Conditioning, Aerobic Exercise, Quality of Life, Oxygen Consumption

\section{Introduction}

Stroke is a clinical syndrome with a presumed vascular origin, characterized by rapidly developing clinical signs of focal or global symptoms due to changes in cerebral functions lasting for more than 24 hours or leading to death [1]. Nowadays, it is one of the most prevalent diseases among the elderly people and it is also the most important cause of chronic disability worldwide and the main cause of death [2]-[4]. The risk of stroke doubles for each successive decade after age 55 and between the ages of $55-75$. The incidence is $50 \%$ higher in men than in women, and the risk for recurrent vascular events is significant and may vary according to the stroke physiopathology, comorbidities and risk factors related to the life style [5]-[7]. Although most of the stroke is not acutely fatal in the first event, the majority of the individuals post-stroke die of complications result from disability or new vascular events [5]-[9]. There are several risk factors for stroke as: hypertension, tobacco use, excessive salt and alcohol intake, overweight, diabetes mellitus, hypercholesterolemia, coagulation disorders and physical inactivity [2] [5]. In general, patients show functional limitations after a stroke (reduced mobility, balance disorders and muscular weakness), predisposing to the lack of activity and sedentary behavior [10] [11]. Although many of these are included in Physical Rehabilitation (Phys Rehab), the main goal is to recover patient's function, posture control, motor control of the affected side, not including approaches to prevent future circulatory events, decreasing the risk factors or to change the natural history of disease [5] [7] [12]-[14].

Recent studies have shown that individuals after stroke not only have motor and cognitive residual impairment but also poor ability to bear physical effort, where about $70 \%$ of them show some type of coexistent heart disease [4] [13] [15]. Along with that, the energy those individuals spend in order to perform their daily life activities (DLA) is significantly greater than the individuals with no functional deficit [4] [16]. Although this poor skill to perform physical efforts may be attributed to the regular aging process, studies have demonstrated that the aerobics fitness in these individuals is approximately $40 \%$ lower than the one found in sedentary individuals of the same gender and age, which can contribute with the increased risk of a future stroke or Acute Myocardial Infarction (AMI) [17] [18]. The benefits of aerobics fitness on cardiovascular risk factors have been extensively demonstrated by decreasing the blood pressure (BP), weight and LDL-cholesterol, improving the glucose and lipids metabolism and also endothelial function and increasing HDL-cholesterol, which improves the rheological properties of blood, therefore decreasing the risk of coronary and cardiovascular diseases (CVD) in general [5] [19] [20]. Recent studies have shown that the risk of having a stroke is lower in active and very active individuals when compared to sedentary and lightly active individuals [5] [21]-[23]. However, many questions about aerobic fitness and stroke are still not well understood. Based on these important issues, the main goal of the present study is to perform a systematic literature review to answer the following clinical question: Should aerobics fitness be part of the Phys Rehab of individuals post-stroke? The secondary goals are to evaluate the effects of aerobic fitness on the quality of life (QoL), complications, mortality and peak oxygen uptake $\left(\mathrm{VO}_{2 \text { peak }}\right)$ of individuals post-stroke. In order to do that, this review included secondary studies evaluating the PICOS question: Patient (post-stroke), Intervention (aerobic exercise), Comparison (treated X control), Outcome ( $\mathrm{VO}_{2 \text { peak }}$, QoL, complications and mortality) and methodogical design (systematic reviews).

\section{Methods}

\subsection{Inclusion Criteria, Database, Search Strategies, Selection and Data Collection Process}

Inclusion criteria involved systematic reviews with or without meta-analysis in English, published in secondary databases (Cochrane, PEDro, Pubmed) searched were from October to November 2012 (Table 1), only in human beings who had stroke, involving all types and severity, published from 2000-2012 and available for free in the internet. The intervention should include the aerobic exercise (AE) and the following outcomes: $\mathrm{VO}_{2 \text { peak, }}$ QoL, 
Table 1. Search strategies.

Cochrane e Pubmed

(Aerobic exercise OR Aerobic training OR Cardio workout OR Aerobic workout OR Aerobic conditioning OR Physical conditioning OR Cardiovascular conditioning OR Cardiovascular rehabilitation OR Physical fitness OR Resistance training OR physical exercise OR Exercise therapy OR Physical endurance OR Physical therapy OR Cardiopulmonary and metabolic rehabilitation) AND (Stroke OR Cerebral stroke OR Brain vascular accident OR Cerebrovascular apoplexy OR Cerebrovascular stroke OR CVA OR Apoplexy OR Cerebrovascular accident)

PEDro*

1. Aerobic exercise

2. Aerobic training

3. Cardio workout

4. Aerobic workout

5. Aerobic conditioning

6. Physical conditioning

7. Cardiovascular conditioning

8. Cardiovascular rehabilitation

9. Physical fitness

10. Resistance training

11. Physical exercise

12. Exercise therapy

13. Physical endurance

14. Physical therapy

15. Cardiopulmonary and metabolic rehabilitation

16. Stroke

17. Cerebral stroke

18. Brain vascular accident

19. Cerebrovascular apoplexy

20. Cerebrovascular stroke

21. CVA (cerebrovascular accident)

22. Apoplexy

23. Cerebrovascular accident

24. 1 and or/16 - 23

25. 2 and or/16 - 23

26. 3 and or/16 - 23

27. 4 and or/16 - 23

28. 5 and or/16 - 23

29. 6 and or/16 - 23

30. 7 and or/16 - 23

31.8 and or/16 - 23

32. 9 and or/16 - 23

33. 10 and or/16 - 23

34. 11 and or/16 - 23

35. 12 and or/16 - 23

36. 13 and or/16 - 23

37. 14 and or/16 - 23

38. 15 and or/16 - 23

mortality and complications. The selected keyword was "stroke" and all equivalent terms identified in the database Medical Subject Headings-MESH, combined with the intervention "aerobic exercise" and the specific correlated words identified at MESH (Table 2). Some articles selected in the database mentioned above were not available, however they were found through Internet-Google for free. The articles were selected by two reviewers based on the titles that approached the disease and intervention. The first reviewer (Suzuki, IFA) collected 
Table 2. Research terms related to CVA and aerobic exercise based on MESH.

\begin{tabular}{cc}
\hline Aerobic Exercise & Stroke \\
\hline Aerobic exercise & Stroke \\
Aerobic training & Cerebral Stroke \\
Cardio workout & Brain Vascular Accident \\
Aerobic workout & Cerebrovascular Apoplexy \\
Aerobic conditioning & Cerebrovascular Stroke \\
Physical conditioning & CVA (Cerebrovascular Accident) \\
Cardiovascular conditioning & Apoplexy \\
Cardiovascular rehabilitation & Cerebrovascular Accident \\
Physical fitness & \\
Resistance training & \\
Physical exercise & \\
Exercise therapy & \\
Physical endurance & \\
Physical therapy & \\
Cardiopulmonary and metabolic rehabilitation & \\
\hline
\end{tabular}

the articles according to the inclusion criteria and the second (Gonçalves, RL) repeated the search to improve accuracy. Any disagreement between the two reviewers was solved through a discussion.

\subsection{Exclusion Criteria}

The poor description of the intervention performed and lack of uniformity concerning type, intensity, frequency, duration of the exercise made the analysis of benefits of the aerobic conditioning after stroke difficult, besides the variety of outcomes used. Numerous studies that analyzed the effect of aerobic conditioning in a stroke patient used gait speed and 6-minute walking test (WT6M) as outcomes. Although there was sufficient evidence to incorporate AE involving walking within post-stroke Phys Rehab to improve speed, tolerance and independence during walking [24], these outcomes are not necessarily good indicators of aerobic conditioning improvement, although they might improve with the increase of $\mathrm{VO}_{2 \text { peak }}$. Often, after a stroke, individuals show functional deficits that harm their gait. Functional gains and learning through repetition that, not necessarily, are associated with the aerobic conditioning improvement, might improve the ability to walk (mobility) and, therefore, increase gait speed and distance covered in the WT6M. Because of that, articles that considered as outcomes the distance covered during the WT6M or gait speed were excluded. Some studies included the weight-supported treadmill. Since there is no study with a good methodological quality assessing the effects of this equipment in providing aerobic conditioning in individuals post-stroke and/or evidencing how safe this method is, studies that included the weight-supported treadmill were also excluded. The lack in the categorization of the description concerning the use of medicines might have contributed to the risk of bias in the results, mainly because the majority of stroke patients have CVD and might take beta-blockers that change the response to exercise.

\subsection{Methodogical Quality Assessment}

Two independent review authors documented the methodological quality of all studies included by using two instruments: Preferred Reporting Items for Systematic reviews and Meta-Analyses (PRISMA [24] Checklist 2009 available at http://www.prisma-statement.org) and Revised Assessment of Multiple Systematic Reviews (R-AMSTAR) [25] [26] and resolved any disagreements by discussion.

\subsection{Data Collection and Data Analysis}

The data were collected according to the outcomes and scrutinized by study. The relevant features of each article 
were discriminated (Table 3 and Table 4). During the description of results, the duplicated articles were identified (Table 4). The data were analyzed using descriptive statistics. The results were analyzed by two independent reviewers.

\subsection{Description of the Physical Activity and Aerobic Exercise}

Physical activity is defined as any bodily movement produced by skeletal muscles that results in energy expenditure beyond resting expenditure [20]. According to the American College of Sports Medicine (ACSM), exercise is a subset of physical activity that is planned, structured, repetitive, and purposeful in the sense that improvement or maintenance of physical fitness is the objective. AE is a kind of physical exercise where the primary source of energy is generated by processes that depend on oxygen $\left(\mathrm{O}_{2}\right)$. Frequently, it lasts from $20-40 \mathrm{~min}$

Table 3. Relevant features of each article.

\begin{tabular}{|c|c|c|c|c|}
\hline Study & Patients & Intervention & Results & Clinical \\
\hline Pang et al., 2006. & $\begin{array}{l}480 \text { individuals with } \\
\text { light or moderate } \\
\text { impairment-7 } \\
\text { randomized clinical } \\
\text { essays. }\end{array}$ & $\begin{array}{l}\text { —Exercise for } 20 \text { - } 40 \text { min, } 3 \text { - } 5 \\
\text { times/week, intensity } 50 \% \text { - } 80 \% \text { of } \\
\text { the HHR. } \\
\text { - Cycle ergometer training was the } \\
\text { most used intervention ( } 4 \text { studies). } \\
\text { — Treadmill walking was used in one } \\
\text { study. } \\
\text { —A combination of walking, brisk } \\
\text { walking and sit-to stand exercise was } \\
\text { used in one study. } \\
\text {-Aerobic exercises in the water } \\
\text { used in one study. }\end{array}$ & $\begin{array}{l}\text {-Improvement in VO2 } \\
(9.0 \%-34.8 \%) \text { in all studies }\end{array}$ & $\begin{array}{l}\text { - There is a good evidence } \\
\text { to support that aerobic } \\
\text { exercise improves aerobic } \\
\text { capacity in individuals with } \\
\text { stroke. } \\
\text { - The results might be } \\
\text { generalized in case of } \\
\text { individuals with a light or } \\
\text { moderate impairment caused } \\
\text { by a stroke, showing a } \\
\text { relative low risk of heart } \\
\text { complications during the } \\
\text { exercises. }\end{array}$ \\
\hline Stoller et al., 2012. & $\begin{array}{l}423 \text { individuals with } \\
\text { light or moderate } \\
\text { impairment-10 } \\
\text { randomized clinical } \\
\text { essays or randomized } \\
\text { controlled pilot } \\
\text { studies and } 1 \\
\text { combined prospective } \\
\text { controlled design. }\end{array}$ & $\begin{array}{l}\text { —Cycle ergometer training of lower } \\
\text { limbs ( } 5 \text { studies) and treadmill ( } 4 \\
\text { studies) were the most used } \\
\text { interventions. } \\
\text { —Class circuit-based training was } \\
\text { used in one study } \\
\text { —Combination of cycle ergometer } \\
\text { training of lower limbs, treadmill, } \\
\text { aerobic exercises with stepping and } \\
\text { cycle ergometer of upper limbs ( } 2 \\
\text { studies). } \\
\text {-Training for } 3 \text { - } 13 \text { weeks, } 20 \text { - } 90 \\
\text { min, } 2 \text { - } 5 \text { times/week, intensity } 40 \% \\
\text { - } 80 \% \text { of HR at rest. }\end{array}$ & $\begin{array}{l}\text { —VO2peak evaluated in } 3 \text { studies } \\
\text { (173 individuals) with significant } \\
\text { favorable results. }\end{array}$ & \\
\hline Meek et al., 2003. & $\begin{array}{l}75 \text { individuals-3 } \\
\text { controlled trials. }\end{array}$ & $\begin{array}{l}\text { —Duncan et al. performed super- } \\
\text { vised exercises (cycle ergometer } \\
\text { training or walking for } 20 \text { min). } \\
\text { —Potempa et al. performed cycle } \\
\text { ergometer training for } 30 \text { min. } \\
\text { — Teixeira-Salmela et al. used } \\
\text { aerobic and strength } \\
\text { classes. } \\
\text {-Training lasted } 10 \text { weeks, was } \\
\text { performed } 3 \text { times/week for } 30 \text { - } 90 \\
\text { min. }\end{array}$ & $\begin{array}{l}\text {-Outcomes were quite } \\
\text { different, making the combination } \\
\text { and/or comparison of results } \\
\text { difficult. } \\
\text { —-No significant result was found } \\
\text { when the outcomes were } \\
\text { combined. } \\
\text { - Significant results were found in } \\
\text { studies individually published. }\end{array}$ & $\begin{array}{l}\text {-Currently, the controlled } \\
\text { clinical trials show } \\
\text { insufficient evidence to } \\
\text { conclude that cardiovascular } \\
\text { exercise is beneficial for } \\
\text { stroke patients. } \\
\text { - Trials to investigate the } \\
\text { cardiovascular exercise } \\
\text { efficacy in stroke patients is } \\
\text { necessary }\end{array}$ \\
\hline $\begin{array}{l}\text { Brazzeli et al., } \\
2011 .\end{array}$ & $\begin{array}{l}1412 \text { individuals-32 } \\
\text { randomized clinical } \\
\text { studies. }\end{array}$ & $\begin{array}{l}\text {-Cardiorespiratory training in } 14 \\
\text { studies ( } 651 \text { individuals), } 2 \text { studies } \\
\text { evaluated a circuit-based training, } \\
1 \text { study was based on water } \\
\text { exercises and the others on cycle } \\
\text { ergometer training (4), treadmill (5) } \\
\text { and electrical bicycle (2). The } \\
\text { sessions were performed } 2 \text { - } 5 \\
\text { times/week, for } 2 \text { - } 12 \text { weeks, from } \\
30 \text { - } 60 \text { min, and the intensity ranged } \\
\text { from } 50 \% \text { - } 85 \% \text { of the participants' } \\
\text { maximal HH, < } 60 \% \text { HRR } \\
\text { (light-vigorous intensity). }\end{array}$ & $\begin{array}{l}\text { —Adverse effects: it was not } \\
\text { systematically reported, however in } \\
\text { some studies the occurrence of a } \\
\text { stroke before the end of the training } \\
\text { is mentioned. } \\
\text {-Physical Skill: Cardiorespiratory } \\
\text { Training-4 studies ( } 120 \text { individuals) } \\
\text { improve in VO2peak. } \\
\text {-QoL: cardiorespiratory training-1 } \\
\text { study ( } 28 \text { individuals) analyzed and } \\
\text { found significant outcomes. }\end{array}$ & \\
\hline
\end{tabular}


Table 4. Primary articles used in the studies included.

\begin{tabular}{|c|c|c|c|c|c|}
\hline Study & Primary articles included & Authors & Duplicates & $\begin{array}{l}\text { Articles in which } \\
\text { this article was } \\
\text { included }\end{array}$ & Year \\
\hline \multirow{9}{*}{$\begin{array}{l}\text { I-The use of aerobic } \\
\text { exercise training in } \\
\text { improving aerobic } \\
\text { capacity in individuals } \\
\text { with stroke: a } \\
\text { meta-analysis. Pang et } \\
\text { al., } 2006 \text {. }\end{array}$} & $\begin{array}{l}\text { 1. Physiological outcomes of aerobic exercise } \\
\text { training in hemiparetic stroke patients. }\end{array}$ & $\begin{array}{l}\text { Potempa K, Lopez M, } \\
\text { Braun LT, Szidon JP, Fogg } \\
\text { L, Tincknell T. }\end{array}$ & yes & I, III e IV & 1995 \\
\hline & $\begin{array}{l}\text { 2. The effect of aerobic training on rehabilitation } \\
\text { outcomes after recent severe brain injury: a } \\
\text { randomized controlled evaluation. }\end{array}$ & $\begin{array}{l}\text { Bateman A, Culpan J, } \\
\text { Pickering AD, Powell JH, } \\
\text { Scott OM, Greenwood RJ. }\end{array}$ & yes & I e III & 2001 \\
\hline & $\begin{array}{l}\text { 3. A comparison of regular rehabilitation and } \\
\text { regular rehabilitation with supported treadmill } \\
\text { ambulation training for acute stroke patients. }\end{array}$ & $\begin{array}{l}\text { da Cunha Filho IT, Lim } \\
\text { PAC. }\end{array}$ & yes & - & 2001 \\
\hline & $\begin{array}{l}\text { 4. Gait outcomes after acute stroke rehabilitation } \\
\text { with supported treadmill ambulation training: a } \\
\text { randomized controlled pilot study. }\end{array}$ & $\begin{array}{l}\text { da Cunha IT, Lim PA, } \\
\text { Qureshy H, Henson H, } \\
\text { Monga T, Protas EJ. }\end{array}$ & yes & I, II e III & 2002 \\
\hline & $\begin{array}{l}\text { 5. Randomized clinical trial of therapeutic exer- } \\
\text { cise in subacute stroke. }\end{array}$ & $\begin{array}{l}\text { Duncan P, Studenski S, } \\
\text { Richards L, et al. }\end{array}$ & yes & I, II e III & 2003 \\
\hline & $\begin{array}{l}\text { 6. The influence of early aerobic training on the } \\
\text { functional capacity in patients with } \\
\text { cerebrovascular accident at the subacute stage. }\end{array}$ & $\begin{array}{l}\text { Katz-Leurer M, Shochina } \\
\text { M, Carmeli E, Friedlander } \\
\text { Y. }\end{array}$ & yes & I e II & 2003 \\
\hline & $\begin{array}{l}\text { 7. The effect of early aerobic training } \\
\text { on independence six months post } \\
\text { stroke. }\end{array}$ & $\begin{array}{l}\text { Katz-Leurer M, Carmeli E, } \\
\text { Shochina M. }\end{array}$ & yes & I e II & 2003 \\
\hline & $\begin{array}{l}\text { 8. Water-based exercise for cardiovascular fitness } \\
\text { in people with chronic stroke: a randomized } \\
\text { controlled trial. }\end{array}$ & $\begin{array}{l}\text { Chu KS, Eng JJ, Dawson } \\
\text { AS, Harris JE, Ozkaplan } \\
\text { A, Gylfadottir S. }\end{array}$ & no & - & 2004 \\
\hline & $\begin{array}{l}\text { 9. A community-based fitness and mobility } \\
\text { exercise (FAME) program for older adults with } \\
\text { chronic stroke: a randomized controlled trial. }\end{array}$ & $\begin{array}{l}\text { Pang MYC, Eng JJ, } \\
\text { Dawson AS, McKay HA, } \\
\text { Harris JE. }\end{array}$ & no & - & 2005 \\
\hline \multirow{11}{*}{$\begin{array}{l}\text { II-Effects of } \\
\text { cardiovascular } \\
\text { exercise early after } \\
\text { stroke: systematic } \\
\text { review and } \\
\text { metaanalysis. } \\
\text { Stoller et al., } 2012 \text {. }\end{array}$} & $\begin{array}{l}\text { 1. Gait outcomes after acute stroke rehabilitation } \\
\text { with supported treadmill ambulation training: A } \\
\text { randomized controlled pilot study. }\end{array}$ & $\begin{array}{l}\text { da Cunha IT, Lim PA, } \\
\text { Qureshy H, Henson H, } \\
\text { Monga T, Protas EJ. }\end{array}$ & yes & I, II e III & 2002 \\
\hline & $\begin{array}{l}\text { 2. A randomized, controlled pilot study of a } \\
\text { home-based exercise program for individuals with } \\
\text { mild and moderate stroke. }\end{array}$ & $\begin{array}{l}\text { Duncan P, Richards L, } \\
\text { Wallace D, et al. }\end{array}$ & no & - & 1998 \\
\hline & $\begin{array}{l}\text { 3. Randomized clinical trial of therapeutic } \\
\text { exercise in subacute stroke. }\end{array}$ & $\begin{array}{l}\text { Duncan P, Studenski S, } \\
\text { Richards L, et al. }\end{array}$ & yes & I, II e III & 2003 \\
\hline & $\begin{array}{l}\text { 4. Aerobic treadmill plus Bobath walking training } \\
\text { improves walking in subacute stroke: a } \\
\text { randomized controlled trial. }\end{array}$ & $\begin{array}{l}\text { Eich HJ, Mach H, Werner } \\
\text { C, Hesse S. }\end{array}$ & no & - & 2004 \\
\hline & $\begin{array}{l}\text { 5. The effect of early aerobic training on } \\
\text { independence six months post stroke. }\end{array}$ & $\begin{array}{l}\text { Katz-Leurer M, Carmeli E, } \\
\text { Shochina M. }\end{array}$ & yes & I e II & 2003 \\
\hline & $\begin{array}{l}\text { 6. The influence of early aerobic training on the } \\
\text { functional capacity in patients with } \\
\text { cerebrovascular accident at the subacute stage. }\end{array}$ & $\begin{array}{l}\text { Katz-Leurer M, Shochina } \\
\text { M, Carmeli E, Friedlander } \\
\text { Y. }\end{array}$ & yes & I e II & 2003 \\
\hline & $\begin{array}{l}\text { 7. The influence of autonomic impairment on } \\
\text { aerobic exercise outcome in stroke patients. }\end{array}$ & $\begin{array}{l}\text { Katz-Leurer M, Shochina } \\
\text { M. }\end{array}$ & no & - & 2007 \\
\hline & $\begin{array}{l}\text { 8. Early post-stroke physical conditioning in } \\
\text { hemiplegic patients: A preliminary study. }\end{array}$ & $\begin{array}{l}\text { Letombe A, Cornille C, } \\
\text { Delahaye H, et al. }\end{array}$ & no & - & 2010 \\
\hline & $\begin{array}{l}\text { 9. Effects of a high-intensity taskoriented training } \\
\text { on gait performance early after stroke: a pilot } \\
\text { study. }\end{array}$ & $\begin{array}{l}\text { Outermans JC, van Peppen } \\
\text { RPS, Wittink H, Takken T, } \\
\text { Kwakkel G. }\end{array}$ & no & - & 2010 \\
\hline & $\begin{array}{l}\text { 10. Effects of an Aerobic Exercise } \\
\text { Program on Aerobic Capacity, Spatiotemporal } \\
\text { Gait Parameters, and Functional Capacity in } \\
\text { Subacute Stroke. }\end{array}$ & $\begin{array}{l}\text { Tang A, Sibley KM, } \\
\text { Thomas SG, et al. }\end{array}$ & no & - & 2009 \\
\hline & $\begin{array}{l}\text { 11. Feasibility, safety and efficacy of an early } \\
\text { aerobic rehabilitation program for patients after } \\
\text { minor ischemic stroke: A pilot randomized } \\
\text { controlled trial. }\end{array}$ & $\begin{array}{l}\text { Toledano-Zarhi A, Tanne } \\
\text { D, Carmeli E, Katz-Leurer } \\
\text { M. }\end{array}$ & no & - & 2011 \\
\hline
\end{tabular}




\section{Continued}

III-Physical fitness training for stroke patients. Brazzeli et al., 2011.
1. A study on the quality of life in ischaemic vascular accidents and its relation to physical activity.

2. Does functional strength training of the leg in subacute stroke improves physical performance? A pilot randomized controlled trial.

3. The effect of aerobic training on rehabilitation outcomes after recent severe brain injury: a randomized controlled evaluation.

4. Efficacy of functional strength training on restoration of lower limb motor function early after stroke: phase I randomized controlled trial.

5. Effect of the Kinetron II on gait and functional outcome in hemiplegic subjects.

6. Gait outcomes after acute stroke rehabilitation with supported treadmill training: a randomized controlled pilot study.

7. Effects of conventional physicaltherapy and functional strength training on upper limb motor recovery after stroke: a randomized phase II study.

8. A randomized, controlled pilot study of a home-based exercise program for individuals with mild and moderate stroke.

9. Randomized clinical trial of therapeutic exercise in subacute stroke.

10. Aerobic treadmill training plus physiotherapy improves walking ability in subacute stroke patients.

Aidar FJ, Silva AJ, Reis

VM, Carniero A

no

Carniero-Cotta S.

Bale M, Strand LI.

no

Bateman A, Culpan FJ,

Pickering AD, Powell JH, yes I e III 2001

Scott OM, Greenwood RJ.

Cooke EV, Tallis RC

Clark A, Pomeroy VM.

Cuviello-Palmer ED.

da Cunha IT, Lim PA,

Qureshy H, Henson H, yes

Monga T, Protas EJ.

I, II e III

Donaldson C, Tallis R,

Miller S, Sunderland A, no

Lemon R, Pomeroy V.

Duncan P, Richards L, Wallace D, et al.

Duncan P, Studenski S, Richards L, et al.

I, II e III

政, Parchmann $\mathrm{H}$ Hesse S, Mach H, Werner no

11. Progressive resistance training after stroke: effects resistance training after stroke: effects on muscle strength, muscle tone, gait performance and perceived participation.

12. Effects of isokinetic training on the rate of movement during ambulation in hemiparetic patients.

13. Effectiveness of functional training, active exercise, and resistive exercise for patients with hemiplegia.

14. Closed kinetic chain training to enhance muscle power, control and retrain dynamic balance under task specific conditions improves functional walking ability in chronic stroke survivors.

15. The effect of early aerobic training on independence six months post stroke.

16. Effects of isokinetic strength training on walking in persons with stroke: a double-blind controlled pilot study.

17. Stroke patients and long-term training: is it worthwhile? A randomized comparison of two different training strategies after rehabilitation.

18. A pilot randomized controlled trial to evaluate the benefit of the cardiac rehabilitation paradigm for the nonacute ischaemic stroke population.

19. Stroke: a randomized trial of exercise or relaxation.

20. Locomotor training improves daily stepping activity and gait efficiency in individuals post stroke who have reached a "plateau" in recovery.
C.

Flansbjer UB, MillerM,

Downham D, Lexell J.

Glasser L.

1986

InabaM, Edberg E, Montgomery J, GillisMK.

James JEP.

Katz-Leurer M, Carmeli E, Shochina M.

Kim CM, Eng JJ,

MacIntyre DL, Dawson no n - n 2001

AS.

Langhammer B, Lindmark $\mathrm{B}$, Stanghelle JK.

Lennon O, Carey A,

Gaffney N, Stephenson J, no n - _ 2008

Blake C.

Mead GE, Greig CA,

Cunningham I, et al.

no

Moore JL, Roth EJ, Killian 


\section{Continued}

IV-A systematic review of exercise trials post stroke. Meek et al., 2003.
21. Circuit-based rehabilitation improves gait endurance but not usual walking activity in chronic stroke: a randomized controlled trial.

22. High-intensity resistance training improves muscle strength, selfreported function, and disability in long-term stroke survivors.

23. Speeddependent treadmill training in ambulatory hemiparetic stroke patients: a randomized controlled trial.

24. Physiological outcomes of aerobic exercise training in hemi paretic stroke patients.

25. Task-specific physical therapy for optimization of gait recovery in acute stroke patients.

26. The role of technology in task oriented training in persons with subacute stroke: a randomized controlled trial.

27. A task-orientated intervention enhances walking distance and speed in the first year post stroke: a randomized controlled trial.

28. Regenerate: assessing the feasibility of a strength training program to enhance the physical and mental health of chronic post stroke patients with depression.

29. Treadmill training post stroke: are there any secondary benefits? A pilot study.

30. Muscle strengthening and physical conditioning to reduce impairment and disability in chronic stroke survivors.

31. A randomized controlled comparison of upper-extremity rehabilitation strategies in acute stroke: a pilot study of immediate and long-term outcomes.

32. Taskoriented progressive resistance strength training improves muscle strength and functiona performance in individuals with stroke.

1. Muscle strengthening and physical conditioning Teixeira-Salmela LF, to reduce impairment and disability in chronic stroke survivors.

2. A randomised controlled pilot study of a home-based exercise program for individuals with Duncan P, Richards L, mild and moderate stroke.

3-Physiological outcomes of aerobic exercise training in hemiparetic stroke patients.

Hanley JA, Richards CL, no Wallace D et al.

no

Mudge S, Barber PA, Stott NS.

Ouellette MM, LeBrasseur no

Pohl M, Mehrholz J, Ritschel C, Ruckriem S. no

Potempa K, Lopez M,

Braun LT, Szidon JP, Fogg yes I, III e IV 1995

L, Tincknell T.

Richards CL, Malouin F,

Wood-Dauphinee S,

Williams JI, Bouchard JP, no

Brunet D.

Richards CL, Malouin F,

Bravo G, Dumas F,

no

2004

Salbach NM, Mayo NE

Wood-Dauphinee S,

Côté R.

Sims J, Galea M, Taylor

$\mathrm{N}$, et al.

Smith PS, Thompson M. no

Teixeira-Salmela LF,

Olney SJ, Nadeau S,

Brouwer B.

yes

Winstein CJ, Rose DK,

Tan SM, Lewthwaite R, no

Chui HC, Azen SP.

Yang YR, Wang RY, Lin

KH, Chu MY, Chan RC.

no

Olney SJ, Nac

Brouwer B.

yes

III e IV

Potempa K, Lopez M,

Braun L, Szidon P, Fogg yes $\mathrm{L}$, Tincknell $\mathrm{T}$.
1999

2004

2006

1998

1995

with a light-moderate intensity [20]. If regularly performed, it might improve cardiorespiratory fitness, explained as the ability of an individual to absorb, transport and use $\mathrm{O}_{2}$. In general, this ability is expressed as maximal oxygen uptake $\left(\mathrm{VO}_{2 \max }\right.$ or $\left.\mathrm{VO}_{2 \text { peak }}\right)$ providing endurance, allowing the individual to perform physical activity for extended period of time or without undue fatigue [23] [27].

\section{Results}

\subsection{Study Selection}

The initial search resulted in 860 articles, where 23 [5] [10]-[13] [19] [21] [24] [28]-[42] potentially relevant 
were selected, based on titles that addressed the disease (stroke), intervention (AE) and outcome criteria. They were fully read. Nineteen [5] [11] [19] [21] [28]-[42] articles were excluded because they did not approach AE, associated it with other interventions or presented other outcome variables (Table 5). Four systematic literature reviews were included in the present study (Table 3 and Table 4). The flowchart related to the study selection is shown in Figure 1.

\subsection{Characteristics of the Studies and Methodological Quality of the Included Reviews}

The relevant characteristics of included studies for this analysis are shown in Table 3 and Table 4. All articles were in English and published in journals from 2003 to 2012. As for the database of the included studies, except for the study performed by Stoller et al. that was only found at Pubmed, all others were found in the three database investigated. All included articles were registered in the Center for Reviews and Dissemination (CRD), except Stoller et al. The studies which described the dysfunction degree of post-stroke individuals included individuals with a light-moderate motor deficit. However, the time between the stroke and beginning of the intervention varied among the studies or was not informed. The stroke stratification in acute, sub-acute or chronic based on the onset was also different among the studies. There was no stratification by gender or type of stroke. In studies with a follow-up, the follow-up period was not informed. Primary common studies were utilized in all four reviews included (Table 4). According to PRISMA checklist none of the studies showed all essential items for the necessary transparency and a good systematic review (Table 6). According to R-AMSTAR, the classification of the scientific evidence power related to the systematic reviews was: B-Brazzelli et al., C-Pang et al., and D-Meek et al. and Stoller et al. (Table 7).

\subsection{Intervention}

The AE intensity ranged from $50 \%$ - 80\% heart rate reserve (HRR), $40 \%-70 \% \mathrm{VO}_{2 \text { peak }}$, from $50 \%$ - $80 \%$ maximum heart rate (MHR), a perceived exertion of 11 - 14 on the Borg scale (Scale 6 - 20), for 20 - 60 min, 3 - 7

\begin{tabular}{|c|c|}
\hline Study & Reason for exclusion \\
\hline Cooke et al., 2010. & Study did not address physical conditioning \\
\hline Chen MD, Rimmer JH, 2011. & Study did not address physical conditioning \\
\hline Wendel-Vos et al., 2004. & Study excluded aerobic exercise and address leisure activities \\
\hline Lopopolo et al., 2006. & Study did not address physical conditioning \\
\hline Kwakkel et al., 2004. & Study did not address physical conditioning \\
\hline French et al., 2010. & Study did not address physical conditioning \\
\hline Harris JE, Eng JJ, 2010. & Study did not address physical conditioning \\
\hline Verbeek et al., 2011. & Study did not address physical conditioning \\
\hline Reimers et al., 2009. & Study did not specify physical activities, includes more than aerobic exercise \\
\hline Wevers et al., 2009. & Study did not address physical conditioning \\
\hline van de Port et al., 2007. & Outcome was gait \\
\hline States et al., 2009. & Outcome was gait \\
\hline McGeough et al., 2009. & Study addressed fatigue and drug treatment \\
\hline English C, Hillier SL, 2010. & Study did not address physical conditioning \\
\hline States et al., 2009. & Study addressed gait training \\
\hline Moseley et al., 2005. & Study addressed gait training \\
\hline An M, Shaughnessy M, 2011. & Study did not address physical conditioning \\
\hline Ovando et al., 2010. & Study did not follow the criteria inclusion and it is in Portuguese \\
\hline Chong et al., 2003. & Study approached several types of physical activity, including leisure activities \\
\hline
\end{tabular}




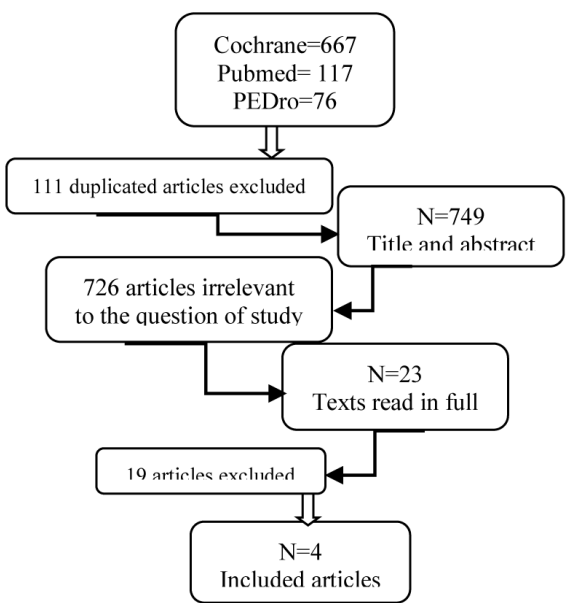

Figure 1. Algorithm of the selection of included articles.

Table 6. PRISMA results of systematic reviews.

\begin{tabular}{ccc}
\hline Study & Score & Max Score \\
\hline Pang et al., 2006. & 21 & 27 \\
Stoller et al., 2012. & 23 & 27 \\
Meek et al., 2003. & 16 & 27 \\
Brazzeli et al., 2011. & 21 & 27 \\
\hline
\end{tabular}

Table 7. R-AMSTAR of systematic reviews.

\begin{tabular}{cccc}
\hline Study & Score & Maximum score & Classification \\
\hline Pang et al., 2006. & 34 & 44 & $\mathrm{C}$ \\
Stoller et al., 2012. & 30 & 44 & $\mathrm{D}$ \\
Meek et al., 2003. & 29 & 44 & $\mathrm{D}$ \\
Brazzeli et al., 2011. & 39 & 44 & B \\
\hline
\end{tabular}

Subtitle: the item was scored according to the questionnaire (annex). The score followed the criteria proposed by R-AMSTAR: A Quality-100\% - 90\% (score 44 - 40); B Quality-89\% - 80\% (score 39 - 36); C Quality-79\% - 70\% (score 35 - 31); D Quality < 69\% (score < 31).

times/week and intensity ranging, according to the ACSM, from very light to vigorous.

\section{Outcomes}

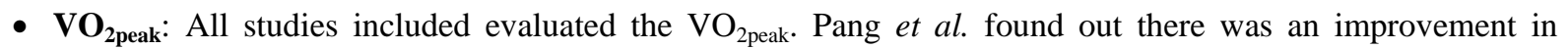
$\mathrm{VO}_{2 \text { peak }}$ in all studies analyzed, ranging from 9-34.8\%. Stoller et al. carried out three studies evaluating the $\mathrm{VO}_{2 \text { peak }}$ which demonstrated homogenous effects in favor of the intervention group. Meek et al. have concluded that due to the limited number of participants in the few primary studies included in their review, insufficient evidence was identified to establish if aerobic conditioning post-stroke has a positive effect, although Potempa et al. have individually demonstrated an improvement in $\mathrm{VO}_{2 \text { peak }}$. Brazzeli et al. have shown also in improvement in $\mathrm{VO}_{2 p e a k}$ in four studies.

\section{Complication}

- Recurrent stroke: Stroke recurrence was addressed in three of the studies included. Pang et al. found that one (Duncan et al.) of the seven studies reported stroke recurrence. In this study, 6\% of the subjects had a recurrent stroke during the exercise trial. Two of the strokes occurred in the beginning of the intervention and one occurred at seven weeks. That is, the incidence rate of recurrent stroke reported was comparable to the recurrent stroke risk reported in the general stroke population (8\% between 1 - 6 months after stroke). Stoller et al. reported that in one study two individuals in the control group during the follow-up had stroke recurrence and the 
same was demonstrated by Pang et al. since they used the same primary study. Brazelli et al. reported that in 15 trials including post-intervention follow-up, seven participants (three in the intervention group and four in the control group) had a recurrent stroke between the end of the intervention and the follow-up. Another study informed that three participants (one in the intervention group and two in the control group) also had another stroke between the beginning and end of the intervention. Besides that, four participants (three in the intervention group and one in the control group) had a stroke between the beginning and end of the intervention.

- Mortality: One study included in this review evaluated mortality. Brazzelli et al. reported there were insufficient data to determine the influence of fitness training on mortality.

- QoL: Three of the studies included in the review discussed the QoL. Stoller et al. have shown favorable results in one study. On the other hand, Meek et al. concluded that although two primary studies included in a review have demonstrated an improvement in the QoL after aerobic fitness (Duncan et al. and Teixeira-Salmela et al.), not enough evidences were found to confirm this information. Brazzelli et al. analyzed the QoL and concluded there was a significant improvement (Aidar et al.). However there was no significant result in another study (Kim et al.) and two others showed good results concerning the function [43]-[47], nevertheless the social aspect was not satisfactory (Duncan et al. and James et al.). Three studies performed by Duncan et al., James et al., Mead et al. demonstrated significant results which were also observed during the follow-up, but another study (Duncan et al.) showed a significant improvement that was not present in the follow-up.

\section{Discussion}

There was "good" evidence for the inclusion of AE on Phys Rehab of post-stroke individuals to improve their physical capacity $\left(\mathrm{VO}_{2 \text { peak }}\right)$, facilitating the completion of its ADL and gait. However, we could not assess if this outcome was kept after the Phys Rehab. The results related to the QoL in response to physical conditioning suggest it might be beneficial in stroke victims. Although there were insufficient evidences for a strong recommendation, based on the results the inclusion of AE to improve the QoL post-stroke with a "weak" level of evidence. There were insufficient results to evaluate the effect of AE on the risk of falls in stroke recurrence, occurrence of a cardiovascular event post-stroke and mortality.

Stroke is a preventable and treatable disease. Physiopathologically, stroke is the result of hypoxic brain cells damage or death due to the interruption of blood flow in part of the brain. As a consequence, depending on the affected brain area there will be damage, dysfunction and/or disability being the reason that most of these individuals will be included in a Phys Rehab [40]. Rehabilitation is a heterogeneous set of therapeutic interventions including numerous interventions, making the result analysis and evidence syntheses difficult [14]. According to the Clinical Practice Guideline for Management of Stroke Rehabilitation [48] (CPGMSR) the Phys Rehab of recent post-stroke patients should: prevent the stroke recurrence, manage the comorbidities, recover the function and prevent complications. Guidelines [7] [9] [14] [22] [48] have shown that victims of stroke when treated by a multidisciplinary team, in centers specialized in strokes, as soon as possible have a better recovery. However, several studies included in this review were carried out in single centers with a small number of participants, many different techniques and approaches, decreasing the statistic power of the evidence.

Currently, stroke has been considered as a global public health problem in elderly people [1] [2] [6] [9]. It is one of the leading causes of morbimortality in most of developed and developing countries, being also considered the most important cause of disability worldwide [6]. It is estimated that 3-6 months after stroke, approximately $15 \%$ - $40 \%$ of the victims will be unable to walk independently at home and only $18 \%$ will show skills to walk with no restriction [11] [39] [49]. A review performed in the United Kingdom revealed that about 50\% of all stroke survivors will still have severe functional deficits six months after stroke onset and approximately $53 \%$ will still depend on other people to perform DLA [11]. Although recent studies in neuroscience and clinical research have demonstrated that the brain is able to significantly recover after a stroke [5], according to CPGMSR $40 \%$ of stroke victims will show a moderate functional impairment, 30\% - 50\% severe incapacity and $15 \%$ - 30\% persistent deficits. The degree of acute paresis has been the most important predictor of motor recovery in this individual [49].

Stroke victims are at heightened risk of having new vascular events and the most of the victims will have a recurrent stroke or AMI, especially in the first year after the initial event [4]. However, although several stroke survivors are being included in Phys Rehab, such programs mainly include techniques and approaches based on mobilization and functional exercises [3]. The secondary prevention of new vascular events was not an imperative goal. Therefore, the Phys Rehab will promote little or no change in the cardiovascular risk factors and the 
natural history of disease [4] [21]. Every third brain vascular event has a fatal outcome [4]. Lee et al. concluded that the risk of stroke or of fatal stroke is lower in very physically active persons than in those whose level of physical activity is low. Alevizos et al. concluded that exercise reduce the risk of stroke. Reimers et al. found that the risk of a fatal and non-fatal ischemic stroke was $24 \%$ lower in active women and $27 \%$ lower in active men, while the risk of hemorrhagic stroke decreased $8 \%$ in active women and $40 \%$ in active men.

It has been shown that the low aerobic capacity is a risk factor for CVD and stroke [10] [11] [48]. However, although the association between the $\mathrm{AE}$ and health improvement is well-established in the general population [10] [20], it is not clear yet if this finding can be extrapolated for stroke patients. Although physical activity is a normal human function that might be safely performed for most of the individuals, including stroke patients, these individuals are often inactive or sedentary due to functional impairments (reduction in mobility, balance deficit and muscular weakness) [10] [11] [20]. According to Gordon et al. it is common that stroke survivors show poor physical capacity, demonstrated by reduced $\mathrm{VO}_{2 \text { peak }}$, indicating that these individuals were already physically inactive before the vascular event. According to Brazelli et al. this low aerobic capacity can be explained by some factors direct or indirectly related to stroke: low level of physical activity before the event, advanced age, presence of comorbidities, direct neurological effect of stroke decreasing the muscular mass available for the activation, decrease or loss of functional skills after the event (as limitation, impairment or incapacity to walk, stand, climb stairs) and muscular weakness [24]. $\mathrm{VO}_{2 \text { peak }}$ is a variable that reflects the systemic adjustment in the $\mathrm{O}_{2}$ transportation and muscular metabolism, as well as the integration between the respiratory, cardiac, vascular and muscular system, responsible for the $\mathrm{O}_{2}$ uptake, transport and use and it has been related to the functional capacity in the elderly [49]. Recent studies have demonstrated a correlation between the $\mathrm{VO}_{2 \text { peak }}$ and the individuals capacity of living independently where an individual only needs approximately 10 $\mathrm{ml}^{-1} \cdot \mathrm{kg}^{-1} \cdot \mathrm{min}^{-1}$ of $\mathrm{O}_{2}$ to independently perform his/her DLA [24] [48] [50]. It has been shown that the $\mathrm{VO}_{2 \text { peak }}$ in stroke patients is reduced to about $10-17 \mathrm{ml}^{-1} \cdot \mathrm{kg}^{-1} \cdot \mathrm{min}^{-1} 0$ - 30 days after the stroke [9]. In a significant way, Brazzelli et al., Stoller et al. and Pang et al. demonstrated an increase in $\mathrm{VO}_{2 \text { peak }}$ resulting from the aerobic conditioning, showing a good evidence that these individuals may benefit from $\mathrm{AE}$. In general, the $\mathrm{VO}_{2}$ during sub-maximum overload activities, such as bed making and get the house is higher in post-stroke individuals when compared with that of healthy subjects of comparable height and weight. This can possibly be explained by the markedly reduced mechanical efficiency, effect of spasticity or both [4]. Energy expenditure during gait in hemiplegic patients varies with the degree of weakness, spasticity, training, and bracing. Furthermore, in some cases, the debilitating motor effects of a stroke can increase the energy cost of walking up to 2 times that of able-bodied persons [4]. The performance of $\mathrm{AE}$ in this population becomes difficult after those changes experienced by stroke victims. In most of the studies included in this review, the strategies used for aerobic exercise were ergonometric. The majority of them addressed the AE in individuals post-stroke with a light to moderate impairment, in an acute and sub-acute phase, but there was no general consensus among the studies researched in the classification of acute and sub-acute. According to most of the Guidelines [8] [9] [14] [22] [48] the acute phase refers to the period right after the stroke onset ( 0 - 7 days), when most of the patients are hospitalized at the time. Stoller et al. report that the performance of AE during this phase is unclear. In all studies in-

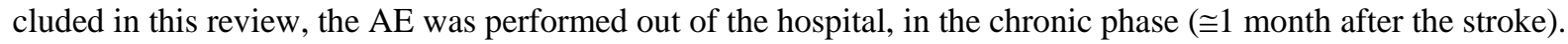
Recent evidences suggest that post-stroke individuals in the outpatient phase might be able to perform activities with an intensity around $50 \%$ of $\mathrm{VO}_{2 \text { peak }}$ being their cardiovascular and metabolic responses to aerobic conditioning comparable to their counterparts of the same age and gender [4]. Gordon et al. address that, although the Phys Rehab of individuals typically ended within 6 months after stroke because it was believed that all recovery of motor function occurred during this interval, recent research studies have shown that aggressive Phys Rehab beyond this time period, including AE might increase aerobic capacity and sensorimotor function.

There is good evidence that the QoL might be improved by physical exercise [20]. However, it was not clear if this result may be extrapolated for stroke victims. Although not all studies included in this review have assessed this outcome or demonstrated unequivocal results, some have demonstrated that aerobic conditioning was able to improve the QoL in post-stroke individuals. However further studies are necessary to establish the level of evidence related to this finding.

There is a vast literature approaching falls in the elderly [51]. However, data related to falls in stroke survivors are limited. Yet, the studies that address the topic have consistently confirmed that it is a common event, after stroke in the acute setting ( $>25 \%$ during Phys Rehab) and in the long term [14]. Studies have demonstrated that approximately $40 \%$ or more stroke victims will fall, at least once, in the first six months after the stroke [7]. 
The risk of fall predictors in stroke victims are scarce and conflicting, but include functional (as weakness), cognitive, sensorial (as the loss of balance) deficits, depression and association of some medicines [48] [51] [52]. A low aerobic capacity is also a major determinant of a poor bone health (osteoporosis) in individuals post-stroke, that predisposes subjects to falls [7]. It is associated to a high morbimortality because of frequent fractures, resulting in the lack of activity, increasing therefore the risk of a new vascular event [4]. Recent studies, as the meta-analysis developed by Sherrington et al. concluded that there are strong evidences that physical exercise decrease the risk of falls in the elderly. However, Quinn et al. found that in post-stroke individuals there was no sufficient evidence to recommend any type of specific exercise to prevent falls. The authors discuss that in Phys Rehab including walking, there was an increase in the number of falls in this population, maybe due to the increased walking frequency. However, the results of the present study were not enough to establish evidences that the increase in the number of falls is a complication resulting from the AE or that aerobic conditioning decreased the number of falls in this population.

According to the ACSM, the risk of sudden death or AMI is very low in healthy adults during activities of moderate intensity [20]. However, the risk of cardiovascular complications increases during vigorous activities, especially in people with latent or documented Coronary Arterial Disease (CAD) or sedentary lifestyle. The ACSM recommends symptom-limited exercise testing before vigorous exercise $\left(>60 \% \mathrm{VO}_{2 \max }\right)$ is undertaken by men $\geq 45$ years and women $\geq 55$ years, those with 2 or more major cardiac risk factors, persons with any signs or symptoms of CAD or those with known cardiac, pulmonary, or metabolic disease [21]. However, recommendations about stress test and parameters for a safer physical exercise in stroke patients have not been found. The CPGMSR [48] recommends that individuals post-stroke should have their vital signs monitored during the Phys Rehab and consider interrupting the therapy when there are sudden changes in HR, BP, temperature, $\mathrm{O}_{2}$ saturation or symptoms such as precordial pain, dyspnea or syncope. None of the studies included in this review addressed the monitoring and vital signs of the participants. Nevertheless, only few complications were described in the included studies and are not different from the ones described for seniors or stroke victims without intervention. The association between $\mathrm{AE}$ and stroke mortality was investigated in healthy men, ranging in age from 40-87 years, in the Aerobics Center Longitudinal Study Database [53]. The 10-year follow up demonstrated that men moderate- and high-fitness groups had a lower risk of stroke death than men who were in the lowest-fitness group at baseline [50]. In the present study only one review addressed mortality as an outcome and did not show any conclusive result. Therefore, no association could be made between AE and mortality in stroke victims.

\section{Conclusion}

Aerobic exercise should be included in the Phys Rehab of stroke survivors which main purpose is to improve the physical capacity, favoring the skill to perform DLA and gait. It is possible that AE improves the QoL in patients with stroke. No conclusions can be drawn stating that $\mathrm{AE}$ is able to decrease the recurrence of stroke, number of falls or mortality.

\section{Clinical Message}

The Phys Rehab of stroke patients might include not only the functional aspects but also measurements to prevent secondary complications, changes in their life style and decrease the risk factors in order to change the natural history of disease.

\section{References}

[1] World Health Organization (1978) Cerebrovascular Disorders: A Clinical and Research Classification. WHO Offset Publication, Geneva.

[2] Feigin, V.L. and Krishnamurthi, R. (2011) Stroke Prevention in the Developing World. Stroke, 42, 3655-3658. http://dx.doi.org/10.1161/STROKEAHA.110.596858

[3] Galvin, R., Murphy, B., Cusack, T. and Stokes, E. (2008) The Impact of Increase Duration of Exercise Therapy on Functional Recovery Following Stroke-What Is the Evidence? Topics in Stroke Rehabilitation, 15, 365-377. http://dx.doi.org/10.1310/tsr1504-365

[4] Gordon, N.F., Gulanick, M., Costa, F., et al. (2004) Physical Activity and Exercise Recommendations for Stroke Survivors: An American Heart Association Scientific Statement from the Council on Clinical Cardiology, Subcommittee on Exercise, Cardiac Rehabilitation, and Prevention; the Council on Cardiovascular Nursing; the Council on Nutrition, 
Physical Activity, and Metabolism; and the Stroke Council. Circulation, 109, 2031-2041. http://dx.doi.org/10.1161/01.CIR.0000126280.65777.A4

[5] Reimers, A.D., Knapp, G. and Reimers, A.K. (2009) Exercise as Stroke Prophylaxis: Review Article. Deutsches Arzteblatt International, 106, 715-721.

[6] Mant, J., Wade, D.T. and Winner, S. (2004) Health Care Needs Assessment: Stroke. In: Stevens, A., Raftery, J., Mant, J., et al., Eds., Health Care Needs Assessment: The Epidemiologically Based Needs Assessment Review, 2nd Edition, Radcliffe Medical Press, Oxford, 141-244.

[7] Intercollegiate Stroke Working Party (2008) National Clinical Guideline for Stroke. 3rd Edition, Royal College of Physicians, London.

[8] Wolfe, C., Rudd, A., Howard, R., Coshall, C., Stewart, J., Lawrwnce, E., et al. (2002) Incidence and Case Fatality Rates of Stroke Subtypes in a Multiethnic Population: The South London Stroke Register. Journal of Neurology Neurosurgery and Psychiatry, 72, 211-216. http://dx.doi.org/10.1136/jnnp.72.2.211

[9] Stroke Foundation of New Zealand and New Zealand Guidelines Group (2010) Clinical Guidelines for Stroke Management. Stroke Foundation of New Zealand, Wellington.

[10] Pang, M.Y.C., Eng, J.J., Dawson, A.S. and Gylfadóttir, S. (2006) The Use of Aerobic Exercise Training in Improving Aerobic Capacity in Individuals with Stroke: A Meta-Analysis. Clinical Rehabilitation, 20, 97-111. http://dx.doi.org/10.1191/0269215506cr926oa

[11] An, M. and Shaughnessy, M. (2011) The Effects of Exercise-Based Rehabilitation on Balance and Gait for Stroke Patients: A Systematic Review. Journal of Neuroscience Nursing, 43, 298-307. http://dx.doi.org/10.1097/JNN.0b013e318234ea24

[12] Stoller, O., de Bruin, E.D., Knols, R.H. and Hunt, K.J. (2012) Effects of Cardiovascular Exercise Early after Stroke: Systematic Review and Meta-Analysis. BMC Neurology, 22, 12-45.

[13] Meek, C., Pollock, A., Potter, J. and Langhorne, P. (2003) A Systematic Review of Exercise Trials Post Stroke. Clinical Rehabilitation, 17, 6-13. http://dx.doi.org/10.1191/0269215503cr579oa

[14] Quin, T.J., Paolucci, S., Sunnerhagen, K.S., Sivenius, J., Walker, M.F. and Less, K.R. (2009) European Stroke Organization (ESO) Executive Committee and the ESO Writing Committee. Evidence-Based Stroke Rehabilitation: An Expanded Guidance Document from the European Stroke Organization (ECO) Guidelines for Management of Ischaemic Stroke and Transient Ischaemic Attack 2008. Journal of Rehabilitation Medicine, 41, 99-111. http://dx.doi.org/10.2340/16501977-0301

[15] Potempa, K., Braun, L.T., Tincknell, T. and Popovich, J. (1996) Benefits of Aerobic Exercise after Stroke. Sports Medicine, 21, 337-346. http://dx.doi.org/10.2165/00007256-199621050-00003

[16] Olney, S.J., Monga, T.N. and Costingan, P.A. (1986) Mechanical Energy of Walking of Stroke Patients. Archives of Physical Medicine and Rehabilitation, 51, 69-77. http://dx.doi.org/10.1016/0003-9993(86)90109-7

[17] Macko, R.F., Smith, G.V., Dobrovolny, C.L., Sorkin, J.D., Goldberg, A.P. and Silver, K.H. (2001) Treadmill Training Improves Fitness Reserve in Chronic Stroke Patients. Archives of Physical Medicine and Rehabilitation, 82, 879-884. http://dx.doi.org/10.1053/apmr.2001.23853

[18] Wilterdink, J.L. and Easton, J.D. (1992) Vascular Disease. Archives of Neurology, 49, 857-863. http://dx.doi.org/10.1001/archneur.1992.00530320089016

[19] Wendel-Vos, G.C.W., Schuit, A.J., Feskens, E.J.M., Boshuizen, H.C., Verschuren, W.M.M., Saris, W.H.M., et al. (2004) Physical Activity and Stroke. A Meta-Analysis of Observational Data. International Journal of Epidemiology, 33, 787-798. http://dx.doi.org/10.1093/ije/dyh168

[20] Haskell, W.L., Lee, I.-M., Pate, R., Powell, K.E., Blair, S.N., Franklin, B.A., et al. (2007) Physical Activity and Public Health: Updated Recommendation for Adults from the American College of Sports Medicine and the American Heart Association. Medicine \& Science in Sports \& Exercise: Special Communications, 39, 1423-1434.

[21] Lee, C.D., Folsom, A.R. and Blair, S.N. (2003) Physical Activity and Stroke Risk: A Meta-Analysis. Stroke, 34, 24752482. http://dx.doi.org/10.1161/01.STR.0000091843.02517.9D

[22] Scottish Intercollegiate Guidelines Network (2010) Part of NHS Quality Improvement Scotland. Management of Patients with Stroke: Rehabilitation, Prevention and Management of Complications, and Discharge Planning: A National Clinical Guideline.

[23] Alevizos, A., Lentzas, J., Kokkoris, S., Mariolis, A. and Korantzopoulos, P. (2005) Physical Activity and Stroke Risk. International Journal of Clinical Practice, 59, 922-930. http://dx.doi.org/10.1111/j.1742-1241.2005.00536.x

[24] Liberati, A., Altman, D.G., Tetzlaff, J., Mulrow, C., Gotzsche, P.C., Loannidis, J.P.A., et al. (2009) The PRISMA Statement for Systematic Reviews and Meta-Analyses of Studies that Evaluate Health Care Interventions: Explanation and Elaboration. Annals of Internal Medicine, 151, W-65-W-94. 
http://dx.doi.org/10.7326/0003-4819-151-4-200908180-00136

[25] Phi, L., Ajaj, R., Ramchandani, M.H., Brant, X.M.C., Oluwadara, O., Polinovsky, O., et al. (2012) Expanding the Grading of Recommendations Assessment, Development, and Evaluation (EX-GRADE) for Evidence-Based Clinical Recommendations: Validation Study. The Open Dentistry Journal, 6, 31-40. http://dx.doi.org/10.2174/1874210601206010031

[26] Kung, J., Chiappelli, F., Cajulis, O.O., Avezova, R., Kossan, G., Chew, L., et al. (2010) From Systematic Reviews to Clinical Recommendations for Evidence-Bases Health Care: Validation of Revised Assessment of Multiple Systematic Reviews (R-AMSTAR) for Grading of Clinical Relevance. The Open Dentistry Journal, 4, 84-91.

[27] Brazzelli, M., Saunders, D.H., Greig, C.A. and Mead, G.E. (2011) Physical Fitness Training for Stroke Patients. Cochrane Database of Systematic Reviews, 9, Article No. CD003316. http://dx.doi.org/10.1002/14651858.cd003316.pub4

[28] French, B., Thomas, L., Leathley, M., Sutton, C., McAdam, J., Forster, A., et al. (2010) Does Repetitive Task Training Improve Functional Activity after Stroke? A Cochrane Systematic Review and Meta-Analysis. Journal of Rehabilitation Medicine, 42, 9-14. http://dx.doi.org/10.2340/16501977-0473

[29] Lopopolo, R.B., Greco, M., Sullivan, D., Craik, R.L. and Mangione, K.K. (2006) Effect of Therapeutic Exercise on Gait Speed in Community-Dwelling Elderly People: A Meta-Analysis. Physical Therapy, 86, 520-540.

[30] Kwakkel, G., Van Peppen, R., Wagenaar, R.C., Wood Dauphinee, S., Richards, C., Ashburn, A., et al. (2004) Effects of Augmented Exercise Therapy Time after Stroke: A Meta-Analysis. Stroke, 35, 2529-2539. http://dx.doi.org/10.1161/01.STR.0000143153.76460.7d

[31] Harris, J.E. and Eng, J.J. (2010) Strength Training Improves Upper-Limb Function in Individuals with Stroke: A Meta-Analysis. Stroke, 41, 136-140. http://dx.doi.org/10.1161/STROKEAHA.109.567438

[32] Cooke, E.V., Mares, K., Clark, A., Tallis, R.C. and Pomeroy, V.M. (2010) The Effects of Increased Dose of ExerciseBased Therapies to Enhance Motor Recovery after Stroke: A Systematic Review and Meta-Analysis. BMC Medicine, 8, 60. http://dx.doi.org/10.1186/1741-7015-8-60

[33] States, R.A., Salem, Y. and Pappas, E. (2009) Overground Gait Training for Individuals with Chronic Stroke: A Cochrane Systematic Review. Journal of Neurologic Physical Therapy, 33, 179-186. http://dx.doi.org/10.1097/NPT.0b013e3181c29a8c

[34] Chen, M.D. and Rimmer, J.H. (2011) Effects of Exercise on Quality of Life in Stroke Survivors: A Meta-Analysis. Stroke. 42, 832-837. http://dx.doi.org/10.1161/STROKEAHA.110.607747

[35] McGeough, E., Pollock, A., Smith, L.N., Dennis, M., Sharpe, M., Lewis, S., et al. (2009) Interventions for Post-Stroke Fatigue. Cochrane Database of Systematic Reviews, 8, Article No. CD007030. http://dx.doi.org/10.1002/14651858.cd007030.pub2

[36] Wevers, L., Van de Port, I.G., Vermue, M., Mead, G. and Kwakkel, G. (2009) Effects of Task-Oriented Circuit Class Training on Walking Competency after Stroke: A Systematic Review. Stroke, 40, 2450-2459. http://dx.doi.org/10.1161/STROKEAHA.108.541946

[37] English, C. and Hillier, S.L. (2010) Circuit Class Therapy for Improving Mobility after Stroke. Cochrane Database of Systematic Reviews, 7, Article No. CD007513. http://dx.doi.org/10.1002/14651858.cd007513.pub2

[38] States, R.A., Pappas, E. and Salem, Y. (2009) Overground Physical Therapy Gait Training for Chronic Stroke Patients with Mobility Deficits. Cochrane Database of Systematic Reviews, 8, Article No. CD006075. http://dx.doi.org/10.1161/strokeaha.109.558940

[39] Moseley, A.M., Stark, A., Cameron, I.D. and Pollock, A. (2005) Treadmill Training and Body Weight Support for Walking after Stroke. Cochrane Database of Systematic Reviews, 19, Article No. CD002840. http://dx.doi.org/10.1002/14651858.cd002840.pub2

[40] Veerbeek, J.M., Koolstra, M., Ket, J.C., van Wegen, E.E. and Kwakkel. G. (2011) Effects of Augmented Exercise Therapy on Outcome of Gait and Gait-Related Activities in the First 6 Months after Stroke: A Meta-Analysis. Stroke, 42, 3311-3315. http://dx.doi.org/10.1161/STROKEAHA.111.623819

[41] Van de Port, I.G., Wood-Dauphinee, S., Lindeman, E. and Kwakkel, G. (2007) Effects of Exercise Training Programs on Walking Competency after Stroke: A Systematic Review. American Journal of Physical Medicine \& Rehabilitation, 86, 935-951. http://dx.doi.org/10.1097/PHM.0b013e31802ee464

[42] Ovando, A.C., Michaelsen, S.M., Dias, J.A. and Herber, V. (2010) Treinamento de marcha, cardiorrespiratório e muscular após acidente vascular encefálico: estratégias, dosagens e desfechos. Fisioterapia em Movimento, 23, 253-269. http://dx.doi.org/10.1590/s0103-51502010000200009

[43] Duncan, P., Studenski, S., Richards, L., Gollub, S., Lai, S.M., Reker, D., et al. (2003) Randomized Clinical Trial of Therapeutic Exercise in Subacute Stroke. Stroke, 34, 2173-2180.

http://dx.doi.org/10.1161/01.STR.0000083699.95351.F2 
[44] Mead, G.E., Greig, C.A., Cunningham, I., Lewis, S.J., Dinan, S., Saunders, D.H., et al. (2007) Stroke: A Randomised Trial of Exercise or Relaxation. Journal of the American Geriatrics Society, 55, 892-899. http://dx.doi.org/10.1111/j.1532-5415.2007.01185.x

[45] Duncan, P., Richards, L., Wallace, D., Stoker-Yates, J., Pohl, P., Luchies, C., et al. (1998) A Randomised Controlled Pilot Study of a Home-Based Exercise Program for Individuals with Mild and Moderate Stroke. Stroke, 29, 2055-2060. http://dx.doi.org/10.1161/01.STR.29.10.2055

[46] Teixeira-Salmela, L.F., Olney, S.J., Nadeau, S. and Brouwer, B. (1999) Muscle Strengthening and Physical Conditioning to Reduce Impairement and Disability in Chronic Stroke Survivors. Archives of Physical Medicine and Rehabilitation, 80, 1211-1217. http://dx.doi.org/10.1016/S0003-9993(99)90018-7

[47] Aidar, F.J., Silva, A.J., Reis, V.M., Carniero, A. and Carniero-Cotta, S. (2007) A study on the Quality of Life in Ischaemic Vascular Accidents and Its Relation to Physical Activity [Estudio de la calidad de vida en el accidente vascular isquémico y su relación con la acividad física]. Revista de Neurología, 45, 518-522.

[48] The American Heart Association/American Stroke Association (2010) VA/DoD Clinical Practice Guideline for the Management of Stroke Rehabilitation.

[49] French, B., Leathley, M., Sutton, C., McAdam, J., Thomas, L., Forster, A., et al. (2008) A Systematic Review of Repetitive Functional Task Practice with Modeling of Resource Use, Cost and Effectiveness. Health Technology Assessment, 12. http://dx.doi.org/10.3310/hta12300

[50] Sherrington, C., Whitney, J.C., Lord, S.R., Herbert, R.D., Cumming, R.G. and Close, J.C.T. (2008) Effective Exercise for the Prevention of Falls: A Systematic Review and Meta-Analysis. The American Geriatrics Society, 56, $2234-2243$. http://dx.doi.org/10.1111/j.1532-5415.2008.02014.x

[51] Kim, C.M., Eng, J.J., MacIntyre, D.L. and Dawson, A.S. (2001) Effects of Isokinetic Strength Training on Walking in Persons with Stroke: A Double-Blind Controlled Pilot Study. Journal of Stroke and Cerebrovascular Diseases, 10, 265-273. http://dx.doi.org/10.1053/jscd.2001.123775

[52] James, J.E.P. (2002) Closed Kinetic Chain Training to Enhance Muscle Power, Control and Retrain Dynamic Balance under Task Specific Conditions Improves Functional Walking Ability in Chronic Stroke Survivors. National University of Ireland, Dublin.

[53] Artero, E.G., Espana-Romero, V., Lee, D.C., Sui, X., Church, T.S., Lavie, C.J., et al. (2012) Ideal Cardiovascular Health and Mortality: Aerobics Center Longitudinal Study. Mayo Clinic Proceedings, 87, 944-952.

http://dx.doi.org/10.1016/j.mayocp.2012.07.015 